\title{
Influence of the Type of Aggregate from Industrial Waste on Corrosion Resistance of Modified Fine-Grained Concrete
}

\author{
Ljajsjan Zajceva ${ }^{1}$, Ekaterina Lucyk ${ }^{1}$, Tat'jana Latypova ${ }^{2}$, Valerij Latypov ${ }^{1, *}$, Pavel Fedorov ${ }^{1}$ (D) \\ and Madina Salamanova ${ }^{3}$ D
}

1 Department of Building Structures, Ufa State Petroleum Technological University, 450064 Ufa, Russia; 01021111@mail.ru (L.Z.); 3505040@mail.ru (E.L.); fpa_idpo@mail.ru (P.F.)

2 Department of Water Supply and Sewerage, Ufa State Petroleum Technological University, 450064 Ufa, Russia; pavlenko_ufa@mail.ru

3 Department Technology of Construction Production, Grozny State Oil Technical University Named after Academician M. D. Millionshchikova, 364061 Grozny, Russia; madina_salamanova@mail.ru

* Correspondence: stexpert@mail.ru; Tel.: +7-347-228-22-00

check for

updates

Citation: Zajceva, L.; Lucyk, E.; Latypova, T.; Latypov, V.; Fedorov, P.; Salamanova, M. Influence of the Type of Aggregate from Industrial Waste on Corrosion Resistance of Modified Fine-Grained Concrete. Buildings 2021, 11, 352. https://doi.org/ 10.3390 /buildings11080352

Academic Editor:

Emilio Bastidas-Arteaga

Received: 15 July 2021

Accepted: 12 August 2021

Published: 14 August 2021

Publisher's Note: MDPI stays neutral with regard to jurisdictional claims in published maps and institutional affiliations.

Copyright: (c) 2021 by the authors. Licensee MDPI, Basel, Switzerland This article is an open access article distributed under the terms and conditions of the Creative Commons Attribution (CC BY) license (https:// creativecommons.org/licenses/by/ $4.0 /)$

\begin{abstract}
The development and implementation of "green" technologies in the construction sector, which ensure natural resource conservation, reduce harmful emissions and provide utilization of industrial waste, are key issues in material engineering of the XXI century. Extensive research has been devoted to solving these issues, including research in the field of concrete science. Still, the issue of developing concrete compositions with increased corrosion resistance remains much less studied. At the same time, reactive aggregates from industrial waste can have positive effect on durability of concrete, and the best result can be achieved by means of modification of a concrete mixture with highly effective additives. The article presents the research data in two lines-the study of applicability of reactive aggregates from waste products of nonmetallic and ceramic industries, mineral wool production and concrete scrap for production of corrosion-resistant concretes, as well as the assessment of possibility of Portland cement quantity reduction in a concrete mixture on local raw materials due to the introduction of additives based on polycarboxylates. The article presents the research evidence of the effect of dust and clay particles content on the quality of concrete with a polycarboxylate additive. The article describes the studies of corrosion resistance of concrete samples based on production wastes in sulfate environments and under the influence of carbon dioxide. The developed concrete compositions with waste use can be recommended for widespread application, rational use of resources, and production of durable high-quality concretes. The application of additives based on polycarboxylates makes it possible to produce concretes with the reduction of cement consumption in the mixture by $10-20 \%$ and decrease in the mode of thermo-wet treatment by two times.
\end{abstract}

Keywords: concrete; waste; quarry fines; concrete scrap; corrosion resistance of concrete

\section{Introduction}

The construction industry is one of the most resource-intensive branches, it forms up to $50 \%$ of all generated solid wastes. The main directions for the development of sustainable construction in this field are associated with the necessity to solve the following tasks: healthy economy support; optimal use of unrenewable resources; preservation of the environment; minimization of damage to biological diversity [1,2].

The researchers [3-7] agree that the application of recycled aggregates is also a promising direction both from the point of view of obtaining high-quality concrete mixtures and from the point of view of ecology and rational use of resources. At the same time, it is important to take into account the peculiarities of aggregates from industrial waste.

Modern building conditions and new complex engineering challenges define the requirements that modern concrete must meet. At the same time, corrosion of various types 
is the main cause of destructive processes taking place in concrete. Expert evaluations of the state of ruining structures and restoration of buildings are expensive activities. Therefore, an important condition for obtaining durable reinforced concrete structures is the rational development of the concrete composition.

It is possible to increase the corrosion resistance of concrete in the conditions of planned aggressive actions by means of its composition optimization in order to:

- Obtain a more compact concrete structure; enhancement of corrosion resistance in this case is caused by a slowdown of aggressive substances penetration into the concrete body;

- Obtain a denser contact zone of a cement matrix with an aggregate; enhancement of corrosion resistance occurs in this case due to decrease in permeability of the weakest zone in the conglomerate- of the contact zone.

Minimization of damage to the environment in the process of concrete manufacturing is possible to achieve through the introduction of modern technologies that allows: To reduce the content of Portland cement in concrete; to use waste from crude ore extraction; to use waste from non-metallic minerals extraction; to use construction waste.

It is known that cement production accounts for up to $7 \%$ of carbon dioxide emissions into the environment [2]. Emissions reduction can be facilitated not only by the modernization of cement production plants, but also by decrease in the cement amount in a concrete composition owing to the introduction of mineral additives (microsilica, fly ash, rock flour) and chemical additives (polycarboxylates, polyacrylates).

It should be noted that the quality of hardened concrete with the use of these additives depends on many factors (the type and consumption of a binder, water-cement ratio, hardening conditions, etc.), as well as on the quality of the aggregates used [3]. In research works $[4,5,8]$ on the study of self-compacting concretes, it is indicated that the used additives based on polycarboxylates are sensitive to the purity of aggregates, namely, to the content of dusty and clay particles. Aggregates with a high content of clay minerals cause a rapid loss of flowability of concrete, which requires the use of an increased amount of polycarboxylate additives to obtain a concrete mixture with the required mobility [5]. The use of unwashed sands containing up to $2 \%$ of clay particles, consisting of kaolinite or hydromicas, practically does not reduce the strength of concrete and the efficiency of application of polycarboxylate superplasticizers [4].

Annually in Russia, over 90 million $\mathrm{m}^{3}$ of exploited mountain massifs remain in disposal areas, which occupy about 1000 hectares [9]. Besides, crushing screenings and rock flour are formed at asphalt concrete factories when breakstone is crushed into required fractions. According to the statistics, the volume of aggregate production in Russia is 508.9 million $\mathrm{m}^{3}$, including 223.9 million $\mathrm{m}^{3}$ of crushed gravel aggregate and 244.2 million $\mathrm{m}^{3}$ of sand. The total explored stone reserve for the European region of Russia is estimated at 15.7 billion $\mathrm{m}^{3}$ [10]. These figures indicate that aggregate supplies are finishing. To increase the percentage of use of natural resources, it is advisable to develop concrete compositions with the application of quarry fines as a concrete aggregate, stone flour as a filler for obtaining multicomponent, self-compacting concretes [11]. This is becoming more and more crucial due to the fact that deposits of raw materials near large cities are getting depleted of their resources.

Cities are developing, old buildings are being demolished, new modern complexes are being made in their place. Demolition of old buildings leads to the formation of construction waste-concrete scrap; currently in Russia the amount of this type of waste equals to about 6 million tons per year. In the coming decades, when panel houses that were built in the 1960s will be withdrawn from use, the amount of construction waste throughout the country will increase. The world experience also speaks for the interest of scientists from India, Japan, USA, Brazil, and Russia to use concrete scrap as a filler in concrete $[1,6,7,12-25]$.

The influence of concrete scrap as a filler on the mechanical and operational properties of concrete depends on many factors, such as the percentage of scrap, fraction size, the 
structure of materials (concrete, ceramics), from which the concrete scrap is formed and other factors as well $[6,7,20,21]$. In the work [6] it is indicated that the deterrent to the application of concrete scrap as a filler is its high water absorption, which contributes to the formation of increased structure porosity that reduces the strength and durability of hardened concrete. Thus, in the work [21] it is noted that the use of $50-100 \%$ coarse aggregate increases the absorption of water by $0.15-0.37 \%$. In turn, in the work [7] it is noted that the replacement of natural aggregates with concrete scrap up to $50 \%$ does not significantly affect the mechanical properties of the self-compacting concretes. In order to improve the structure of concrete with the use of scrap, the authors of the work [7] recommend that at the stage of concrete mix preparation, fractions of concrete scrap should be pretreated with a solution of lithium silicate, which reduces the bond strength in the "aggregate-cement paste" system by means of smoothing the aggregate surface and reducing friction forces. According to the authors of this work, application of polycarboxylate additives appears to be the most rational to reduce the water demand of the concrete mixture.

Studies of physical and mechanical properties of concretes with the application of concrete scrap, described in the work [22], showed that when natural sand is replaced with concrete scrap of fine fractions up to $100 \%$, no reduction in compressive and tensile strength is observed. By the application of coarse fractions, a decrease in the compressive strength of concrete (by about 35\%) was observed in comparison with the reference concrete. In the work [23] it is noted that by the study of rheological properties of self-compacting concrete with the application of concrete scrap of a fine fraction in the amount of more than $50 \%$, a loss of the required concrete workability occurs after 90 minutes from the beginning of gauging. The main reasons for this tendency reside in an initial increase in plastic stickiness and then in an increase in the point of yielding.

The work [24] presents the results of studies of the influence of concrete scrap humidity on the rheological and mechanical properties of concrete. The authors found that when using a dried aggregate, the theoretical amount of absorbed water added at the beginning of mixing leads to a temporary increase in the initial water-cement ratio. On the contrary, absorbed water in a saturated aggregate cannot make for increase of the initial water-cement ratio. The best mechanical properties were shown by concretes with a dried aggregate.

The authors of the research [25] point out that there exists a connection between the moisture content value of the aggregate from concrete scrap and concrete cracking. With an increase in humidity from oven-dried condition to saturated surface-dried condition, resistance of concrete to cracking increases.

One of the criteria for assessing the concrete composition based on production waste is its durability in aggressive environments. The most common are gaseous media (exposure to carbon dioxide) and liquid media (exposure to sodium sulfate and magnesium sulfate solutions).

In making an assessment of concrete durability under the influence of carbon dioxide, the most common research option is performance of an accelerated test by means of increasing gas concentration in the air, ageing for a certain time and then determining the following: the depth of concrete carbonization using indicators, the reaction capacity of concrete, the effective diffusion coefficient, or others characteristic values [26-33]. In order to make assessment of durability of concrete exposed to liquid media, the resistance coefficient [30] is used, defined as the ratio of the compressive strength of concrete kept in a liquid aggressive medium to the compressive strength of concrete kept in water for a certain period of time. The resistance coefficient can also be determined by the ratio of the concrete sample weight in an aggressive environment to the concrete sample weight in water or according to the change in geometric parameters of the working section when exposed to an aggressive environment [31].

There are other methods for evaluation of concrete durability, such as a chloride permeability method [32], determination of electrical resistivity, and others. For example, in the work [20] the diffusion coefficient of concrete, determined by means of the surface 
and volume specific electrical resistance method, is used as a criterion for assessing the durability of concrete with the use of ceramic waste.

Taking these facts into account, the priority in this field must be given to research aimed at proving a solution of the following problems: Development of concrete compositions using waste of various industries as a filler in order to reduce load on the environment; reduction of cement in a concrete mixture and development of concretes with increased corrosion resistance.

\section{Materials and Methods}

In order to solve the set tasks, we have conducted research in two lines. The first line included work on the assessment of possibility of Portland cement quantity reduction in a concrete mixture on local raw materials due to the introduction of additives based on polycarboxylates. The second line of the research was devoted to the study of aggregates from industrial waste to obtain concrete with increased corrosion resistance.

\subsection{Reduction of Cement Consumption Due to Introduction of Additives Based on Polycarboxylates}

The research in the first line was carried out in two stages. At the first stage, the effect of a polycarboxylate additive on fine-grained concrete containing fine aggregate with different contents of dust and clay particles was studied. At the second stage, the possibility of reducing the consumption of cement by $10-20 \%$ and reducing the duration of thermo-wet treatment by two times was investigated using the example of concrete mixture, suitable for the manufacture of reinforced concrete structures.

For the first stage, two identical compositions of fine-grained concrete (by dry components) were selected: composition C1-I-with an increased content of dusty and clay particles in the sand; composition C2-I-with a low content of dust and clay particles in the sand.

At the second stage, five compositions of heavy concrete were taken for the manufacture of piles with an additive based on polycarboxylate with different modes of thermo-wet treatment and binder content. Requirements for this type of construction are as follows: concrete grade $\mathrm{B} 27.5 \mathrm{P} 1,100 \%$ gain in strength after thermo-wet treatment according to the mode $2+4+2=8$ hours.

Distinctive features of the taken compositions are as follows: composition C3-Ireduction of Portland cement by $10 \%$, reduction of thermo-wet treatment by two times; composition C4-I-without reduction of Portland cement, thermo-wet treatment is reduced by two times; composition C5-I-reduction of Portland cement by $10 \%$, thermo-wet treatment is reduced by two times; composition C6-I-reduction of Portland cement by $20 \%$, thermo-wet treatment is reduced by two times; composition C7-I-reduction of Portland cement by $20 \%$, thermo-wet treatment is reduced by two times.

The material consumption for the compositions is shown in Table 1.

Table 1. Compositions for the analysis of influence of a polycarboxylate additive on concrete with different contents of dust and clay particles in fine aggregate.

\begin{tabular}{cccccc}
\hline \multirow{2}{*}{$\begin{array}{c}\text { Types of } \\
\text { Composi- } \\
\text { tions }\end{array}$} & $\begin{array}{c}\text { Consumption of Components per 1 } \mathbf{~ m}^{\mathbf{3}} \text { of a } \\
\text { Concrete Mixture (Parts by Weight) }\end{array}$ & $\begin{array}{c}\text { Water- } \\
\text { Cement } \\
\text { Ratio }\end{array}$ & $\begin{array}{c}\text { Chemical } \\
\text { Additive, \% of the } \\
\text { Binder Weight }\end{array}$ \\
\cline { 2 - 4 } C1-I & 560 & 1680 & - & 0.50 & 1.0 \\
C2-I & 560 & 1680 & - & 0.45 & 1.0 \\
C3-I & 465 & 1310 & 580 & 0.31 & 0.6 \\
C4-I & 515 & 1255 & 555 & 0.36 & 0.6 \\
C5-I & 465 & 1310 & 580 & 0.34 & 0.3 \\
C6-I & 410 & 1370 & 605 & 0.35 & 0.3 \\
C7-I & 410 & 1370 & 605 & 0.39 & 0.6 \\
\hline
\end{tabular}


For the preparation of the compositions, Portland cement of "CEM II/A-S 42.5N" brand produced by "HeidelbergCement Rus LLC" (Sterlitamak, Russia) was used as a binder. The admixture "Glenium ACE 430" manufactured by "BASF" (Germany) was introduced as a polycarboxylate additive. Water corresponding to GOST 23732-2011 [34] was used for gauging of the concrete mixture.

The aggregate was natural quartz sand from the Kabakovo quarry (Kabakovo village, Russia). Fractions of $0.16-2.5 \mathrm{~mm}$ were used as a fine aggregate, and screened sand gravel with a fraction of 5-10 $\mathrm{mm}$ was used as a coarse aggregate. The sand had the following characteristics: fineness modulus $\mathrm{M}_{\mathrm{f}}=2.26$ (medium sand); bulk density of sand in its natural state is $1285 \mathrm{~kg} / \mathrm{m}^{3}$, in the dry state $-1480 \mathrm{~kg} / \mathrm{m}^{3}$, the content of dusty and clay particles is $0.7 \%$, the gravel content in the sand is $1 \%$.

The granulometric composition of the sand is shown in Table 2.

Table 2. Granulometric composition of natural quartz sand.

\begin{tabular}{ccc}
\hline & Residues by Weight, $\%$ & \\
\hline Sieve Sizes & Partial & Full \\
\hline 2.5 & 4.5 & 4.5 \\
1.25 & 6.5 & 11.0 \\
0.63 & 14.5 & 25.5 \\
0.315 & 60.0 & 85.5 \\
0.16 & 13.5 & 99.0 \\
Bottom & 1.0 & 100.0 \\
\hline
\end{tabular}

To study the composition C1-I, we took natural quartz sand from the same quarry as for other compositions, but it was taken from a zone with substandard sands tending to sandy loam. The content of dust and clay particles in them was equal to $2.8 \%$.

In order to compare the compositions, we accepted the following criteria under study: technological properties (cone slump and average density of a concrete mixture as per GOST 10181-2014 [35]), physico-mechanical properties (concrete compression strength within 28 days, concrete bending strength within 28 days according to GOST 10180-2012 [36]) and chemical properties (diffusional carbon dioxide permeability of concrete).

Control cube samples with dimensions $100 \times 100 \times 100 \mathrm{~mm}$ were produced to determine the compression strength and prism samples with dimensions $40 \times 40 \times 160 \mathrm{~mm}$ were made to determine the bending strength. The tests were carried out on a "PGM500MG4" device (compression strength) and on a small-size pressing machine "PM-1MG4" (bending strength).

Determination of the diffusion permeability of concrete to carbon dioxide was carried out in a special chamber for accelerated carbonization of concrete with an automatic system for maintaining a given carbon dioxide concentration and constant thermo-humidity conditions in accordance with GOST 31383-2008 [33], taking into account the recommendations of the authors of the work [26], namely changing the concentration of $\mathrm{CO}_{2}$ from reference values of 10 to $2 \%$ and uniform mixing of gas using a system of low-speed fans installed in the chamber. The carbonization depth index is important from the point of view of evaluation of concrete durability.

The aggressive environment in the chamber had the following features: use rate of $\mathrm{CO}_{2}-2 \pm 0.5 \%$ by volume, temperature $20 \pm 1{ }^{\circ} \mathrm{C}$, relative air humidity $65 \pm 5 \%$. Relative humidity maintenance was carried out by means of a special system of humidification and dehumidification of the air environment. The samples were kept for 45 days. Determination of the carbonization depth was carried out by means of an indicator of a $0.1 \%$ solution of phenolphthalein in ethyl alcohol which was applied on a newly made cleavage of the sample. A crimson color in this case indicates "healthy" non-carbonated concrete with a $\mathrm{pH}$ value of more than 10 , and colorless tinct shows carbonated concrete with a $\mathrm{pH}$ value of less than 10 . 
For comparative assessment of the compositions at the second stage, the criteria for the cone slump in accordance with GOST 10181-2014 [35] were used, as well as the determination of compression strength after thermo-wet treatment and after 28 days of natural hardening. Cubes with dimensions $100 \times 100 \times 100 \mathrm{~mm}$ were taken as control samples.

\subsection{Aggregates from Production Waste in Corrosion-Resistant Concretes}

To increase the corrosion resistance of concrete, it is advisable to use reactive aggregates, which are divided into 2 types depending on the mechanism of coalescence with the cement stone: type I-coalescence occurs at the chemical level, type II-coalescence occurs at the physical level [37].

We have taken into consideration: a reactive aggregate of the first type-waste of mineral wool production, slugs, as well as reactive aggregates of the second type-concrete scrap and expanded clay. Layers of cement stone, which increase the adhesion of the aggregate with the cement matrix, remain on the grains of crushed stone from concrete scrap [37]. From works [2,38] it follows that concrete based on a lightweight expanded-clay aggregate has increased acid resistance, as well as resistance in the sulphate-magnesian environment. Expanded clay provides a dense contact zone between a cement matrix and an aggregate due to its porous structure and physical intergrowth.

For the study, five types of fine-grained concrete compositions with different types of aggregate from industrial waste were selected, namely: composition C1-II-waste from nonmetallic industry during the extraction of crushed stone-quarry fines of gabbrodiorites having magmatic origin from the Sangalyk quarry-OAO "Sangalyksky dioritovyi karyer" (Sangalyk diorite quarry, the village of Mansurovo, Russia); composition C2-II-a mixture of quarry fines and waste of mineral wool production, "slugs", OOO "Agidel" (Blagoveshchensk, Russia); composition C3-II-a mixture of natural quartz sand and waste from ceramic industry - expanded clay gravel and sand, $\mathrm{OOO}$ "Ufimskaya gipsovaya kompaniya" (Ufa Gypsum Company, Ufa, Russia); composition C4-II-a mixture of natural quartz sand and waste from construction or dismantling of buildings and structuresconcrete scrap; composition C5-II is a reference composition obtained with an application of natural quartz sand.

Raw materials consumption for the compositions of the second line of research is shown in Table 3.

Table 3. Compositions of concrete for the second line of research.

\begin{tabular}{|c|c|c|c|c|c|c|c|c|}
\hline \multirow{3}{*}{$\begin{array}{l}\text { Composition } \\
\text { Type }\end{array}$} & \multicolumn{6}{|c|}{ Consumption of Concrete Mix Components, $\mathrm{kg} / \mathrm{m}^{3}$} & \multirow{3}{*}{$\begin{array}{l}\text { Water- } \\
\text { Cement } \\
\text { Ratio }\end{array}$} & \multirow{3}{*}{$\begin{array}{c}\text { Chemical } \\
\text { Additive, } \\
\% \text { of the } \\
\text { Binder } \\
\text { Weight }\end{array}$} \\
\hline & \multirow[b]{2}{*}{ Binder } & \multicolumn{5}{|c|}{ Aggregate } & & \\
\hline & & $\begin{array}{c}\text { Crushed } \\
\text { Stone } \\
\text { Quarry Fines }\end{array}$ & $\begin{array}{c}\text { Waste of } \\
\text { Mineral Wool } \\
\text { Production }\end{array}$ & $\begin{array}{c}\text { Expanded } \\
\text { Clay gravel } \\
\text { and Sand }\end{array}$ & $\begin{array}{l}\text { Concrete } \\
\text { Scrap }\end{array}$ & $\begin{array}{l}\text { Quartz } \\
\text { Sand }\end{array}$ & & \\
\hline C1-II & 650 & 1400 & - & - & - & - & 0.46 & 0.8 \\
\hline C2-II & 650 & 800 & 600 & - & - & - & 0.68 & 0.8 \\
\hline C3-II & 560 & - & - & 300 & - & 1000 & 0.61 & 1.0 \\
\hline C4-II & 560 & - & - & - & 800 & 880 & 0.52 & 1.0 \\
\hline C5-II & 560 & - & - & - & - & 1680 & 0.45 & 1.0 \\
\hline
\end{tabular}

For all the compositions, Portland cement of "CEM II A-S 42.5N" brand produced by "HeidelbergCement Rus LLC" (Sterlitamak, Russia) was used as a binder. The ratio of sand to cement for compositions C1-II and C2-II was 1:2, for compositions C3-II, C4-II, C5-II-1:3. As a chemical admixture, we used an additive based on "MasterGlenium 591" polycarboxylate in the following amounts: for compositions $\mathrm{C} 1-\mathrm{II}$ and $\mathrm{C} 2-\mathrm{II}-0.8 \%$ by weight of cement; for compositions C3-II, C4-II, C5-II-1\% by weight of cement.

In order to create a mixture for compositions C3-II, C4-II and produce a reference composition C5-II, natural alluvial sand from the Kabakovo quarry (Kabakovo village, Russia) was used. 
Crushed stone quarry fines from gabbro-diorites have the following characteristics: the content of fractions larger than $5 \mathrm{~mm}-20.86 \%$; the content of dusty and clay particles$11.25 \%$; fineness module $\mathrm{M}_{\mathrm{f}}=1.91$; bulk density $1650 \mathrm{~kg} / \mathrm{m}^{3}$. The granulometric composition of the quarry fines is shown in Table 4.

Table 4. Granulometric composition of quarry fines.

\begin{tabular}{ccc}
\hline & Residues by Weight, $\%$ & \\
\hline Sieve sizes & Partial & Full \\
\hline 10 & 1.0 & 1.0 \\
5 & 19.8 & 20.9 \\
0.63 & 50.6 & 71.4 \\
0.05 & 26.6 & 98.0 \\
Bottom & 2.0 & 100.0 \\
\hline
\end{tabular}

Waste of mineral wool production (slugs) is a powdery slag represented by a mixture of spherical, needle-shaped, smooth, and sharp-edged particles. In this research it was used as a fine aggregate.

The used expanded clay gravel and sand had following characteristics corresponding to GOST 32496-2013 [39] and GOST 9758-2012 [40]: fraction 0-5 mm; compaction factor 1.15; bulk density $462 \mathrm{~kg} / \mathrm{m}^{3}$.

Concrete scrap was produced by means of size reduction of heavy concrete samples having a B30strength class and made from cement of "CEM II A-S 42.5N" brand produced by "HeidelbergCement Rus LLC" (Sterlitamak, Russia), crushed stone of dolomite fraction 5-20 mm from Bianka quarry (Minyar, Russia), and natural sand from Kabakovo quarry (Kabakovo, Russia).

Granulometric composition of concrete scrap after crushing is shown in Table 5.

Table 5. Granulometric composition of concrete scrap.

\begin{tabular}{ccc}
\hline & Residues by Weight, $\%$ \\
\hline Sieve Sizes & Partial & Full \\
\hline 2.5 & 44.1 & 44.1 \\
1.25 & 14.7 & 58.8 \\
0.63 & 13.8 & 72.6 \\
0.315 & 7.1 & 79.7 \\
0.16 & 4.9 & 84.5 \\
Bottom & 15.5 & 100.0 \\
\hline
\end{tabular}

In order to compare the compositions with one another, we used the cone slump, the density of a concrete mixture as per GOST 10181-2014 [35], concrete watertightness grade performed using the device "BB-2 ("Agama" type) and determined in accordance with GOST 12730.5-2018 [41], compression and bending resistance of concrete samples after 28 days of natural hardening as per GOST 10180-2012 [36]. The tests were carried out: for compression using a "PGM-500MG4" press and for bending using a small-size press model "PM-1MG4".

Corrosion resistance was studied in two media-liquid sulfate medium ( $3 \%$ sodium sulfate solution and $1 \%$ magnesium sulfate solution) and gaseous medium $\left(2 \% \mathrm{CO}_{2}\right.$ concentration).

To test the concrete samples in a sodium sulfate solution, based on the recommendations of previous studies [42], samples were made from the compositions C1-II (standard sample) and C2-II. After exposure to an aggressive environment, three samples of each composition were tested for compression on a "PGM-500MG4" device. The samples were tested at the age of 360 days. 
The study of the corrosion resistance of concretes of compositions C3-II, C4-II, and C5-II was carried out in a solution of magnesium sulfate using the same procedure as for compositions in a solution of sodium sulfate.

To rate the resistance in gas environments, all types of compositions were tested for the diffusional $\mathrm{CO}_{2}$ permeability of concrete, according to the method described in the first line of the research.

Evaluation of corrosion resistance in liquid media was carried out according to the coefficient of resistance - the ratio of the ultimate working capacity for compression strength of the samples stored in an aggressive environment to the compress strength of the samples stored in water. The assessment of resistance in gaseous media was carried out according to the depth of neutralization (carbonization) of concrete, defined using a 0.1 phenolphthalein solution as an indicator.

The study of the structure of concrete samples was carried out by a raster electronic microscopy method on a "JEOL JSM-6610 LV" microscope.

\section{Results}

3.1. Reduction of Cement Consumption Due to the Introduction of Additives Based on Polycarboxylates The test results of the compositions taken for the first stage are shown in Table 6.

Table 6. Test results of the compositions at the first stage.

\begin{tabular}{lcc}
\hline \multicolumn{1}{c}{ Parameters } & \multicolumn{2}{c}{ Types of Compositions } \\
\cline { 2 - 3 } & C1-I & C2-I \\
\hline Cone slump, $\mathrm{cm}$ & 16 & 23 \\
Concrete density, $\mathrm{kg} / \mathrm{m}^{3}$ & 2000 & 2251 \\
Compression strength $\mathrm{R}_{\text {comp }} 28$ days, $\mathrm{MPa}$ & 35.38 & 51.85 \\
Bending strength $\mathrm{R}_{\text {ben }} 28$ days, $\mathrm{MPa}$ & 2.70 & 6.43 \\
\hline
\end{tabular}

With an increase in dust and clay particles content from $0.7 \%$ to $2.8 \%$, the water-cement ratio significantly increases along with less mobility, the density of concrete decreases, its strength reduces by $31 \%$. Even a slight decrease in concrete density is accompanied by a significant increase in its permeability, which can be illustrated by the kinetics of concrete carbonization (Figure 1).

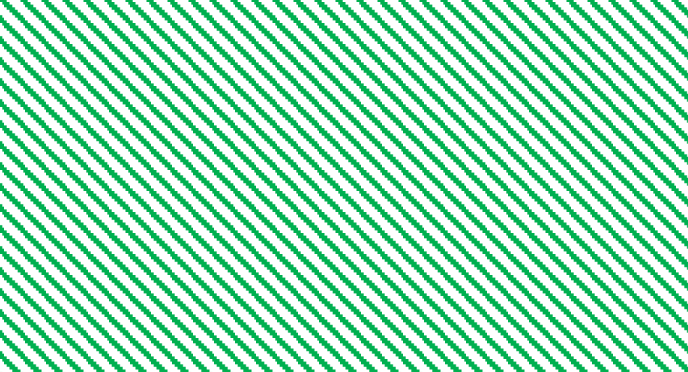

(a)

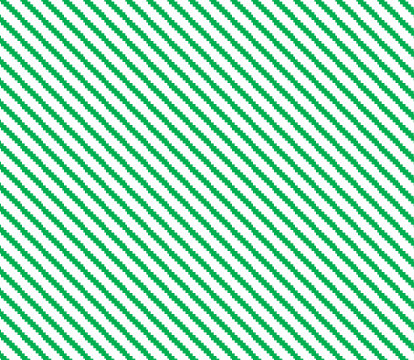

(b)

Figure 1. Images of newly made chips of fine-grained concrete coated with an indicator of $0.1 \%$ phenolphthalein solution: (a) composition C1-I; (b) composition C2-I.

The chips of two compositions depicted in Figure 1 show that the depth of carbonization of concrete with dust and clay particles content of $0.7 \%$ (composition C2-I) was $2.13 \mathrm{~mm}$, whereas the composition of C1-I is completely carbonized.

The research results of the influence of binder consumption and a mode of thermowet treatment of concrete suitable for the production of piles, carried out as a part of the research program of the second stage, are shown in Figure 2. 


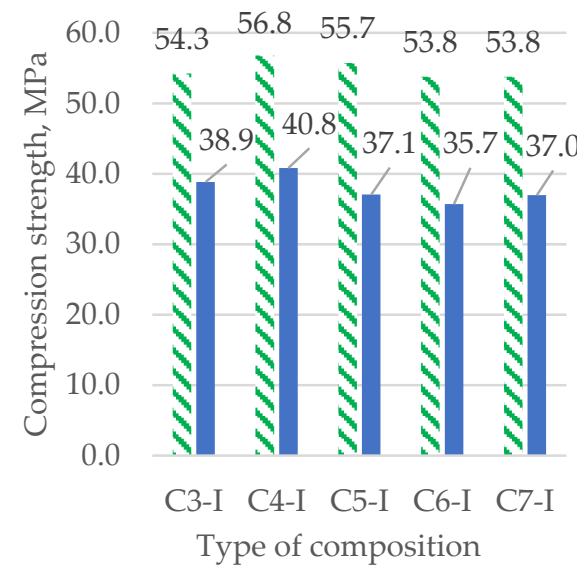

$\checkmark$ Natural hardening within 28 days

After thermo-wet treatment

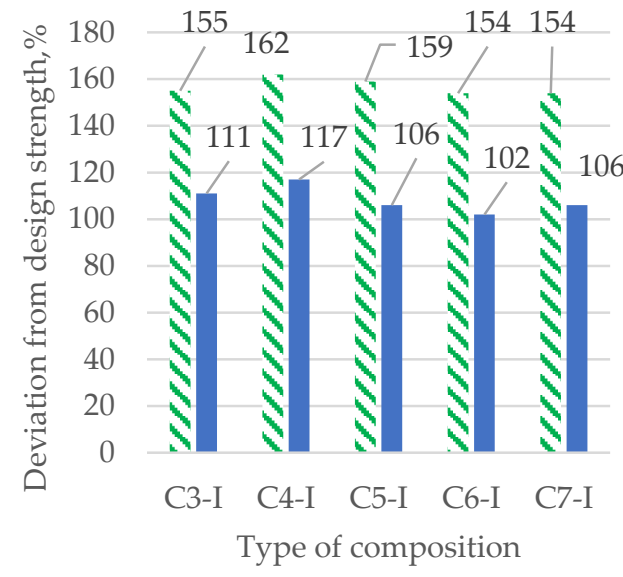

$\$$ Natural hardening within 28 days

After thermo-wet treatment

(a)

(b)

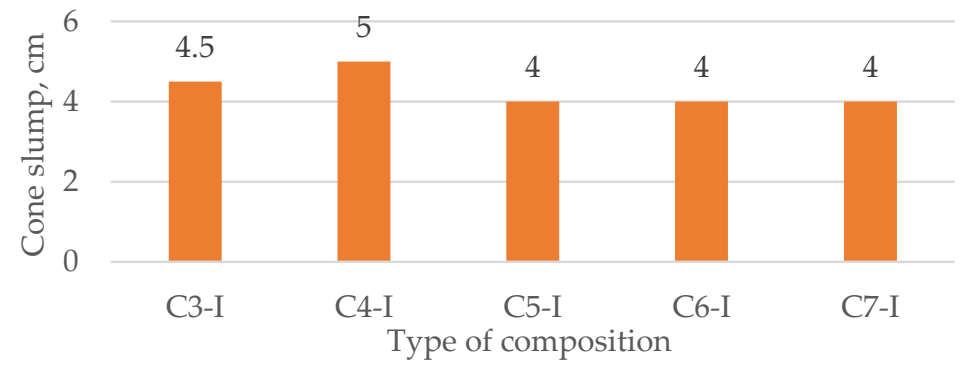

(c)

Figure 2. Research results of control compositions and samples of the second stage of the first line of research: (a) compressive strength of the samples; (b) the deviation of the obtained tensile strength values from the intended strength of $35 \mathrm{MPa}$; (c) concrete slump.

Thus, with reduction in cement consumption by 10 or $20 \%$, as well as with reduction in duration of a thermo-wet treatment, concrete of all tested compositions gains the required strength of $100 \%$.

\subsection{Evaluation of the Effectiveness of Aggregates from Waste}

Prior to the main research, the applied aggregates were examined for the content of active microsilica in them by means of a photocolorimetric method in order to exclude the occurrence of alkaline corrosion in concrete.

Results of determination of soluble silicon dioxide according to the calibration curve by means of a photocolorimetric method are shown in Table 7 .

Table 7. Content of soluble silicon dioxide in the test samples.

\begin{tabular}{lc}
\hline \multicolumn{1}{c}{ Sample Name } & $\mathbf{S i O}_{\mathbf{2}}$ Concentration, $\mathbf{~ m m o l} / \mathrm{L}^{\circ}$ \\
\hline Concrete scrap & 25.28 \\
Natural quartz sand from Kabakovo quarry & 49.13 \\
Quarrry fines of crushed rock from Sangalyk quarry & 11.10 \\
\hline
\end{tabular}

The obtained results meet the requirements of GOST 8267-93 [43], since “... crushed stone and gravel are applied in concrete without restrictions if the content of rocks and minerals classified as harmful components makes no more than $50 \mathrm{mmol} / \mathrm{L}$ of amorphous modifications of silicon dioxide, soluble in alkalis." 
The test results of technological and mechanical properties of different types of concrete compositions are shown in Table 8.

Table 8. Test results in the second line of research.

\begin{tabular}{lccccc}
\hline \multirow{2}{*}{ Parameters } & \multicolumn{3}{c}{ Types of Compositions } \\
\cline { 2 - 6 } & C1-II & C2-II & C3-II & C4-II & C5-II \\
\hline The structure of a concrete mixture & Cohesive & "Spiky" & Fluid & Cohesive & Fluid \\
mixture & mixture \\
Cone slump, $\mathrm{cm}$ & mixture & mixture & 16 & 17 & 20 \\
Density, $\mathrm{kg} / \mathrm{m}^{3}$ & 16 & 2023 & 1186 & 2175 & 2251 \\
Compression strength, $\mathrm{R}_{\text {comp }}$ 28 days, $\mathrm{MPa}$ & 47.88 & 22.00 & 9.33 & 37.66 & 43.98 \\
Bending strength $\mathrm{R}_{\text {ben }}$ 28 days, MPa & 8.80 & 6.06 & 2.65 & 3.74 & 6.43 \\
Water resistance & $\mathrm{W} 14$ & W2 & W16 & W12 & W18 \\
\hline
\end{tabular}

A comparative analysis of corrosion resistance of the involved compositions is shown in Figure 3.

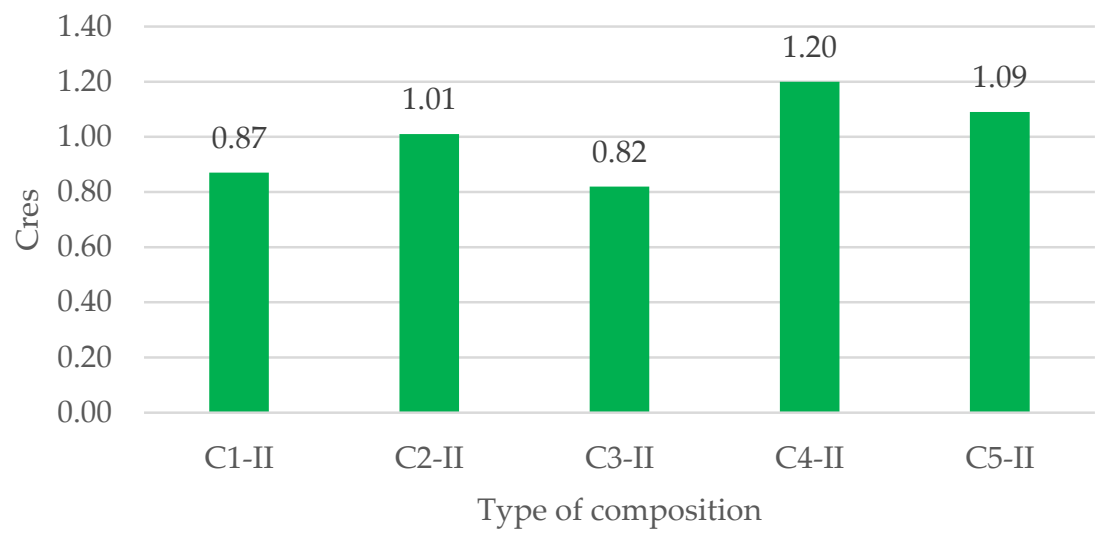

Resistance coefficient denoting ratio of the compression strength of concrete at the age of 360 days in an aggressive environment to the compression strength of concrete at the age of 360 days in water. Cres = Rcomp 360 agres. medium / Rcomp 360.water

(a)

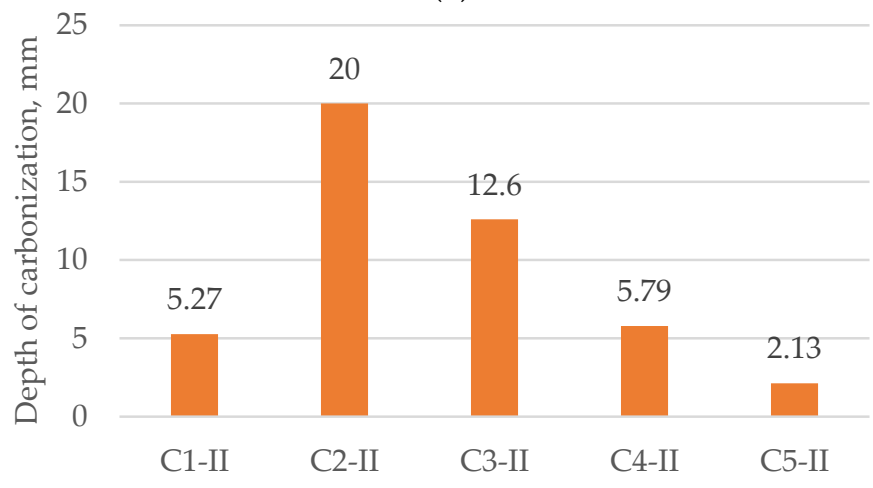

Type of composition

(b)

Figure 3. Evaluation of corrosion resistance of samples of the second line of research: (a) corrosion resistance of samples in liquid media; (b) the depth of concrete carbonization. 
The samples of composition C1-II have the lowest W/C (water/cement) ratio and, as a consequence, the lowest carbonization depth, high rates of strength, and water resistance. Composition C2-II which contains mineral wool production waste has a high W/C ratio due to the roughness of the particles. However, the resistance coefficient of the composition C2-II, based on the waste of mineral wool production, is higher.

Figure 4 presents research results of the samples with the aid of a raster electron microscope "JEOL JSM-6610 LV".

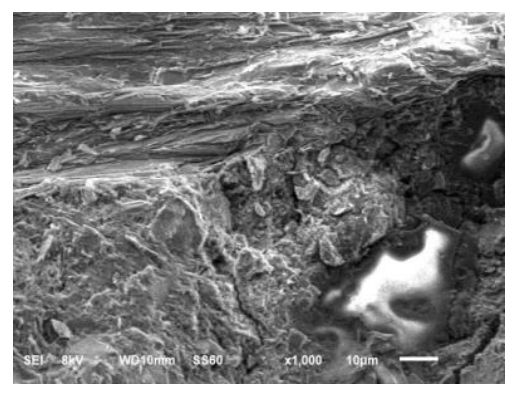

(a)

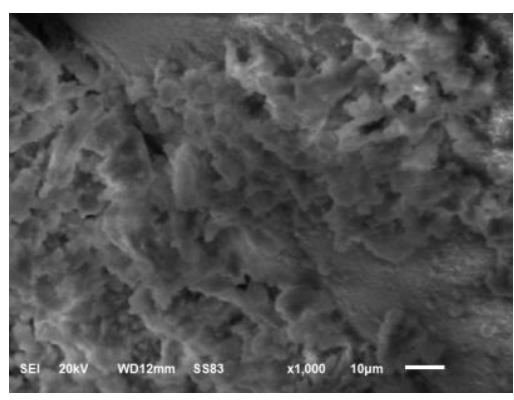

(b)

Figure 4. Contact layer "cement stone-aggregate" through a microscope: (a) composition C1-II; (b) composition C2-II.

In the samples of composition C2-II shown in Figure $4 b$, we can clearly see outgrowths on the aggregate, in contrast to composition C1-II (Figure 4a). Thus, the use of a reactive aggregate based on waste from mineral wool production can be considered promising, since even with sufficiently low values for density and water resistance, this composition has the highest coefficient of resistance due to the intergrowth of the cement matrix and the aggregate.

The compression strength coefficient of a sample based on a concrete scrap aggregate (composition C4-II) is higher than that of the reference specimen (composition C5-II). The resistance coefficient of the sample based on an expanded clay aggregate (composition C3-II) is lower than that of the reference specimen; it is explained by the fact that the porosity of expanded clay neutralizes the positive effect of cement stone coalescence with expanded clay. The results of study of the concrete microstructure of compositions C3-II, C4-II, and C5-II by means of a raster electron microscope are presented in Figure 5.

Images of microstructure of the composition samples C3-II testify that the contact layer "expanded clay-cement stone" is difficult to distinguish, since the microstructure is formed as a whole entity. In samples of composition C4-II, the contact layer "aggregatecement stone" is formed without gaps, however, growths on the aggregate particles are distinguished. As a result, the resistance of concrete based on aggregate from concrete scrap in a magnesium sulfate environment is higher than the resistance of the reference sample based on quartz sand. The images of microstructure of the C5-II composition clearly show that the contact zone "cement stone-natural sand" is highly distinguishable. Therefore, even with the highest strength values, reference composition C5-II has a compression strength coefficient lower than that of the composition C4-II, which also confirms that the use of compositions based on aggregate from concrete scrap allows to obtain more resistant concretes in a magnesium sulfate environment. 


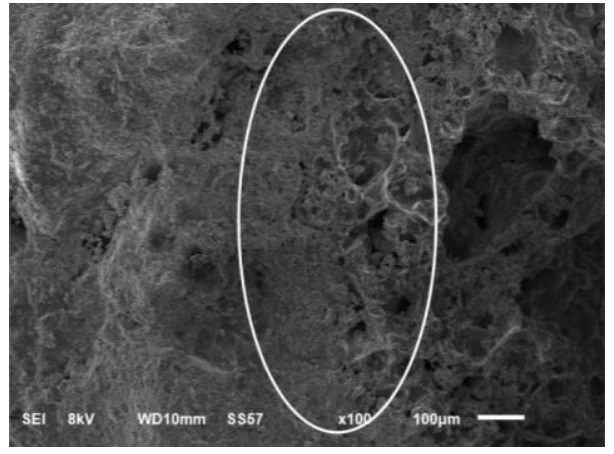

(a)

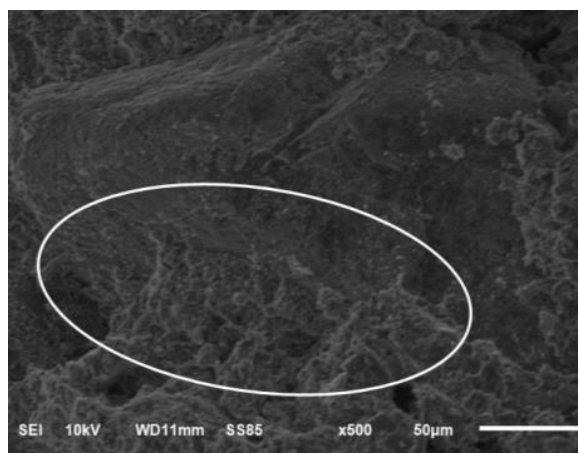

(b)

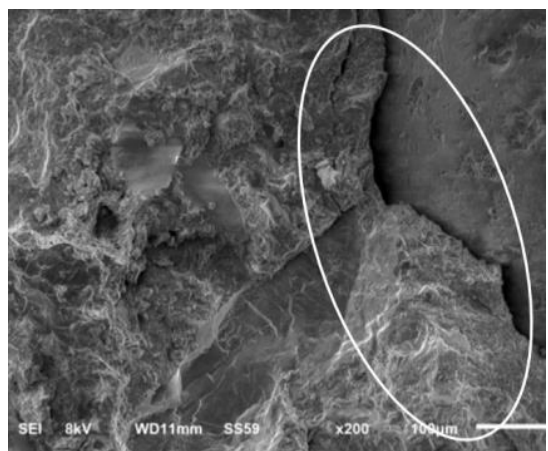

(c)

Figure 5. Contact layer "cement stone-aggregate" through a microscope: (a) composition C3-II; (b) composition C4-II, (c) composition C5-II.

\section{Discussion}

The research data about the influence of dust and clay particles show that with their high content in the aggregate with the introduction of the same amount of a chemical additive, an increase in water demand is required to achieve the intended rheological properties, which confirms the research results given in $[4,5,8]$.

The obtained data indicate that while choosing the composition of concrete, it is important to take into account a certain combination of a binder and an aggregate type and their collaboration under conditions of specific aggressive influences on the structure. Thus, when designing concrete for overground constructions that are not exposed to aggressive spillage, it is advisable to choose concrete involving the application of natural alluvial sand and cement with slag content not exceeding $20 \%$ to ensure high durability of structures under conditions of exposure to carbon dioxide. When designing structures exposed to underground or technogenic water, it is advisable to use an aggregate made of concrete scrap with the application of cement with slag content not exceeding $20 \%$.

These results are in good agreement with the conclusions drawn by the authors of the works [37,42].

High corrosion resistance of the composition C4-II with concrete scrap in comparison with the reference composition C5-II based on natural quartz sand can be explained by the fact that the structure of concrete scrap contains unhydrated binder particles, as well as a high content of dust. First, they contribute to the compaction of the structure and a decrease in the porosity of concrete, and second, they increase the amount of portlandite, one of the main products of cement hydration. However, the compression strength of these samples is $14 \%$ less than that of the reference composition C5-II. A possible reason for the decrease in strength is the defective structure of an aggregate from concrete scrap, which leads to unstable failure of the "aggregate-cement stone" cohesion. On the whole, the 
obtained results are in good agreement with the research evidence received by the authors of the work [23].

To increase the waste utilization from the nonmetallic raw materials extraction so as to rationalize the use of natural resources, reduce the bulk of disposal areas, and enhance the corrosion resistance of concrete, it is advisable to use fine-grained concrete with quarry fines of $0-5 \mathrm{~mm}$ fraction from the Sangalyk quarries (Mansurovo village, Russia).

\section{Conclusions}

The following conclusions can be drawn according to the results of the conducted research:

- The developed compositions of fine-grained concrete with the use of quarry fines of $0-5 \mathrm{~mm}$ fraction can be recommended for the widespread utilization of wastes of nonmetallic raw materials extraction from the Sangalyk quarry (Mansurovo village, Russia) as well as for rational use of resources and production of durable highquality concretes;

- The application of an aggregate from concrete scrap (substitution of $50 \%$ of the aggregate) increases the resistance of concrete in magnesium sulfate environment;

- To produce concretes with high durability, it is important to use only clean washed quartz sands with a content of dust and clay particles not exceeding $1 \%$;

- The use of polycarboxylate-based chemical additives in concretes on local raw materials contributes to a decrease in cement by $10-20 \%$ and a reduction in thermo-wet treatment by two times, without significant losses of the specified service properties.

Author Contributions: Conceptualization, V.L.; Data curation, E.L. and T.L.; Formal analysis, L.Z., E.L., T.L. and M.S.; Investigation, L.Z., E.L., T.L., V.L., P.F. and M.S.; Methodology, L.Z., T.L., V.L., P.F. and M.S.; Project administration, V.L.; Resources, E.L. and T.L.; Software, T.L.; Supervision, T.L.; Validation, V.L.; Visualization, E.L., V.L. and P.F.; Writing - original draft, L.Z., E.L., T.L., V.L. and P.F.; Writing - review \& editing, E.L., V.L. and P.F. All authors have read and agreed to the published version of the manuscript.

Funding: This research received no external funding.

Institutional Review Board Statement: Not applicable.

Informed Consent Statement: Not applicable.

Data Availability Statement: The data presented in this study are available on request from the corresponding author.

Conflicts of Interest: The authors declare no conflict of interest.

\section{References}

1. Murtazaev, S.-A.Y.; Murtazaev, A.T.; Salamanova, M.S. Influence of recycled concrete aggregate on formation of concrete structure and properties. In Science, Education and Production, Proceedings of the All-Russian Scientific-Practical Conference Dedicated to the 95th Anniversary of the Birth of Academician M.D. Millionshchikova, Grozny, Russia, 29 February-1 March 2008; Grozny State Oil Technical Institute named after Academician M.D. Millionshchikova: Grozny, Russia, 2008; pp. 261-264.

2. Gorchakov, G.I. Influence of the properties of coarse aggregate on the corrosion resistance of concrete. News High Educ. Inst. Constr. 1974, 8, 22-23.

3. Jagadesh, P.; Juan-Valdés, A.; Guerra-Romero, M.I.; Morán-del Pozo, J.M.; García-González, J.; Martínez-García, R. Effect of Design Parameters on Compressive and Split Tensile Strength of Self-Compacting Concrete with Recycled Aggregate: An Overview. Appl. Sci. 2021, 11, 6028. [CrossRef]

4. Hickov, A.A.; Ivanov, I.M.; Kramar, L.Y.; Kirsanova, A.A.; Zimich, V.V. Influence of various clay particles on effectiveness of polycarboxylate superplasticizer and properties of cement stone. Bull. South Ural State Univ. 2019, 19, 40-51. [CrossRef]

5. Roslan, M.A.M.; Mohamad, M.A.N.; Omar, S.M. High Quality DNA from Peat Soil for Metagenomic Studies a Minireview on Dna Extraction Methods. Sci. Herit. J. 2017, 1, 1-6. [CrossRef]

6. Poon, C.S.; Kou, S.C.; Lam, L. Influence of Recycled Aggregate on Slump and Bleeding of Fresh Concrete. Mater. Struct. 2007, 40, 981-988. [CrossRef]

7. Tang, W.; Khavarian, M.; Yousefi, A.; Chan, R.W.K.; Cui, H. Influence of Surface Treatment of Recycled Aggregates on Mechanical Properties and Bond Strength of Self-Compacting Concrete. Sustainability 2019, 11, 4182. [CrossRef] 
8. Chen, G.; Lei, J.; Du, Y.; Du, X.; Chen, X. A Polycarboxylate as a Superplasticizer for Montmorillonite Clay in Cement: Adsorption and Tolerance Studies. SI Nanochem. Mater. 2018, 11, 747-755. [CrossRef]

9. Arseniev, V.A. Scientific and Technical Report N 02.525.11.5007: Development of Resource-Saving Technologies and Complex Technological Lines for Multi-Tonnage Waste of Inert Non-Metallic Raw Materials with the Production of Economical Construction Products for Mass Use; Closed Joint Stock Company “Design Bureau” Avtomatika “a subsidiary of JSC" Kirovsky Zavod: St. Petersburg, Russia, 2010.

10. Falikman, V.; Rozental, N.; Rozental, A. AAR in concrete: Russian experience. In RILEM, Proceedings of the Pro128-3 Durability, Monitoring and Repair of Structure, Proceedings of the International Conference on Sustainable Materials Systems and Structures (SMSS2019), Rovinj, Croatia, 20-22 March 2019; RILEM Publications S.A.R.L.: Paris, France, 2019; Volume 3, pp. $192-199$.

11. Butkevich, G.R. Stages of Development of Non-Metallic Building Materials Industry in Russia. Constr. Mater. $2011,1,3-5$.

12. Bedov, A.I.; Tkach, E.V.; Pakhratdinov, A.A. Issues of utilization of concrete scrap waste for the production of large aggregate in the production of reinforced concrete bending elements. Vestn. MGSU 2016, 7, 91-100. [CrossRef]

13. Golovin, M.V.; Kutov, D.V.; Shchigoreva, E.M.; Shchigorev, D.S. Influence of recycled concrete aggregate on corrosion resistance of concrete. In Proceedings of the International Scientific and Technical Conference of Young Scientists BSTU Named after V.G. Shukhov, Belgorod, Russia, 1-20 May 2017; Belgorod State Technological University named after V.G. Shukhov: Belgorod, Russia, 2017; pp. 1489-1493.

14. Thomas, M.; Monkman, S.; Djerbi, A. The carbonation of recycled concrete aggregate affected by alkali-silica reaction. In RILEM, Proceedings of the PRO 133 International Workshop CO2 Storage in Concrete (CO2STO2019), Marne-la-Vallee, France, 24-25 June 2019; RILEM Publications S.A.R.L.: Paris, France, 2019; pp. 138-145.

15. Ekolu, S.O.; Makama, L.N.; Shuluuka, W.P. Influence of different recycled aggregate types on strength and abrasion resistance properties of concrete. In Concrete Repair, Rehabilitation and Retrofitting III, Proceedings of the 3rd International Conference on Concrete Repair Rehabilitation and Retrofitting (ICCRRR), Cape Town, South Africa, 3-5 September 2012; CRC press: Boca Raton, FL, USA, 2012; pp. 72-73.

16. Serna, P.; Ulloa, V.A.; Pelufo, M.J.; Jacquin, C. Analysis of zero-slump concrete made recycled aggregate from concrete demolition waste. In RILEM, Proceedings of the PRO 82 2nd International RILEM Conference on Progress of Recycling in the Built Environment, Sao Paulo, Brazil, 2-4 December 2009; RILEM Publications S.A.R.L.: Paris, France, 2011; pp. 243-252.

17. Gutiérrez, P.A.; Sanchez de Juan, M. Utilization of Recycled Concrete Aggregate for Structural Concrete. In RILEM, Proceedings of the PRO 40 International RILEM Conference on the Use of Recycled Materials in Building and Structures, Barcelona, Spain, 8-11 November 2004; RILEM Publications S.A.R.L.: Bagneux, France, 2004; Volume 2, pp. 693-702.

18. Tanaka, K.; Yada, K.; Maruyama, I.; Sato, R.; Kawai, K. Study on Corrosion of Reinforcing Bar in Recycled Concrete. In RILEM, Proceedings of the PRO 40 International RILEM Conference on the Use of Recycled Materials in Building and Structures, Barcelona, Spain, 8-11 November 2004; RILEM Publications S.A.R.L.: Bagneux, France, 2004; Volume 2, pp. 643-650.

19. Sun, J.; Huaqin, J. Study on Properties of Recycled Concrete Aggregate and Influence of it on Properties of Concrete. In RILEM, Proceedings of the PRO 73 2nd International Conference on Waste Engineering and Management (ICWEM 2010), Shanghai, China, 13-15 October 2010; Curran: New York, NY, USA, 2011; pp. 261-268.

20. Horňáková, M.; Lehner, P. Relationship of Surface and Bulk Resistivity in the Case of Mechanically Damaged Fibre Reinforced Red Ceramic Waste Aggregate Concrete. Materials 2020, 13, 5501. [CrossRef] [PubMed]

21. Grdic, Z.J.; Toplicic-Curcic, G.A.; Despotovic, I.M.; Ristic, N.S. Properties of Self-Compacting Concrete Prepared with Coarse Recycled Concrete Aggregate. Constr. Build. Mater. 2010, 24, 1129-1133. [CrossRef]

22. Silva, F.A.N.; Delgado, J.M.P.Q.; Azevedo, A.C.; Lima, A.G.B.; Vieira, C.S. Preliminary Analysis of the Use of Construction Waste to Replace Conventional Aggregates in Concrete. Buildings 2021, 11, 81. [CrossRef]

23. Carro-López, D.; González-Fonteboa, B.; de Brito, J.; Martínez-Abella, F.; González-Taboada, I.; Silva, P. Study of the Rheology of Self-Compacting Concrete with Fine Recycled Concrete Aggregates. Constr. Build. Mater. 2015, 96, 491-501. [CrossRef]

24. Zhao, Z.; Remond, S.; Damidot, D.; Xu, W. Influence of Fine Recycled Concrete Aggregates on the Properties of Mortars. Constr. Build. Mater. 2015, 81, 179-186. [CrossRef]

25. Ji, T.; Chen, C.-Y.; Chen, Y.-Y.; Zhuang, Y.-Z.; Chen, J.-F.; Lin, X. Effect of Moisture State of Recycled Fine Aggregate on the Cracking Resistibility of Concrete. Constr. Build. Mater. 2013, 44, 726-733. [CrossRef]

26. Fedorov, P.A.; Anvarov, A.R.; Lutsyk, E.V.; Latypov, V.M.; Latypova, T.V. Kinetics of Fine Concrete Carbonation in Humid Operational Environment. Int. J. Appl. Eng. Res. 2016, 11, 7439-7445.

27. Alekseev, S.N.; Rosenthal, N.K. Corrosion Resistance of Reinforced Concrete Structures in Aggressive Industrial Environment; Stroyizdat: Moscow, Russia, 1976.

28. Latypov, V.M.; Fedorov, P.A.; Lutsyk, E.V.; Latypova, T.V. Units for Accelerated Carbonation of Concrete Samples and Repair Compositions. J. Phys. Conf. Ser. 2020, 1515, 042027. [CrossRef]

29. Xuan, D.; Poon, C.S. 16-Sequestration of carbon dioxide by RCAs and enhancement of properties of RAC by accelerated carbonation. In New Trends in Eco-Efficient and Recycled Concrete; Woodhead Publishing: Kidlington, UK, 2019; pp. 477-497, ISBN 978-0-08-102480-5.

30. Latypov, V.M.; Latypova, T.V.; Lutsyk, E.V.; Fedorov, P.A. Durability of Concrete and Reinforced Concrete in Natural Aggressive Environments, 2nd ed.; USPTU Editorial and Publishing Center: Ufa, Russia, 2014; ISBN 978-5-7831-1233-1.

31. Polak, A.F.; Gelfman, G.N.; Yakovlev, V.V. Anticorrosive Protection of Building Structures at Chemical and Petrochemical Enterprises; Bashkir Book Publishing House: Ufa, Russia, 1980. 
32. Nordtest NT BUILD 492. Concrete, Mortar and Cement-Based Repair Materials: Chloride Migration Coefficient from Non-Steady-State Migration Experiments; NORDTEST: Espoo, Finland, 1999.

33. GOST 31383-2008. Protection against Corrosion of Concrete and Reinforced Concrete Constructions. Test Methods; Standartinform: Moscow, Russia, 2010.

34. GOST 23732-2011. Water for Concrete and Mortars. Specifications; Standartinform: Moscow, Russia, 2012.

35. GOST 10181-2014. Concrete Mixtures. Methods of Testing; Standartinform: Moscow, Russia, 2015.

36. GOST 10180-2012. Concretes. Methods for Strength Determination Using Reference Specimens; Standartinform: Moscow, Russia, 2018.

37. Tolypina, N.M.; Shchigoreva, E.M.; Golovin, M.V.; Shchigorev, D.S. Increase of corrosion resistance of concrete by application of active aggregates of the second type. Bull. Belgorod State Technol. Univ. Named V G Shukhov 2019, 4, 27-32. [CrossRef]

38. KuISI. Resistance of Lightweight Building Structures; KuISI: Kuibyshev, Russia, 1973.

39. GOST 32496-2013. Fillers Porous for Light Concrete. Specifications; Standartinform: Moscow, Russia, 2014.

40. GOST 9758-2012. Non-Organic Porous Aggregates for Construction Work. Test Methods; Standartinform: Moscow, Russia, 2014.

41. GOST 12730.5-2018. Concretes. Methods for Determination of Water Tightness; Standartinform: Moscow, Russia, 2019.

42. Rakhimbaev, S.M.; Tolypina, N.M.; Khakhaleva, E.N. Substantiation of methods for testing corrosion resistance of hydration hardening materials. In II International Online Congress "Nature-Like Technologies of Building Composites for the Protection of the Human Environment", Dedicated to the 30th Anniversary of the Department of "Building Materials Science, Products and Structures"; Belgorod State Technological University named after V.G. Shukhov: Belgorod, Russia, 2019; pp. 735-739.

43. GOST 8267-93. Crushed Stone and Gravel of Solid Rocks for Construction Works. Specifications; Standartinform: Moscow, Russia, 2018. 